\title{
Examination of Youth Gangs and Interventions in \\ Three Contexts: American, European, and Turkish Experiences
}

\author{
Dr. Serkan Tasgin (Corresponding author) \\ Turkish National Police \\ Eyyubiye 50.Yil Polis Merkezi Amirligi, Sanliurfa/Turkey \\ Tel: 00-507-489-7591Ｅ-mail: tasginserkan@gmail.com \\ Dr. Gokhan Aksu \\ Turkish National Police \\ Koruma Sube Mudurlugu, Sanliurfa/Turkey \\ Tel: 00-507-134-8059_E-mail: gokhanaksu1@yahoo.com
}

Received: November 17, 2014 Accepted: December 10, 2014 Published: December 16, 2014

doi:10.5296/jsss.v2i1.6635 URL: http://dx.doi.org/10.5296/jsss.v2i1.6635

\begin{abstract}
The purpose of this article is to examine gang problem and intervention strategies in American, European, and Turkish contexts. Although there is a lack of common definition of gang and gang membership in the extant literature leading to overestimation and underestimation of the problem, research on gangs in both American and European contexts is promising. In all three contexts, there are different risk factors for gang membership and hence, interventions focused on different aspects and contexts such as suppression, community mobilization, school based interventions and so on. Gang problem and related intervention and prevention strategies are relatively new and not comprehensive partly in European and mostly in Turkish contexts. However, intervention and prevention strategies are mostly evidence-based and theory oriented in American context. This study can further our understanding for developing intervention and prevention strategies to deal with gang
\end{abstract}


problem.

Keywords: Gang, Intervention, Prevention, Eurogang, Supression, Troublesome youth group

\section{Introduction}

Youth violence is a broad concept that involves several offense types. Youth gang is one of them and needs special attention, because youth gangs are also inherently connected to other offense types such as youth homicide and drug trafficking. Moreover, gang members are more delinquent, more violent than non-gang youth and gang members are more likely to experience victimization than non-gang delinquents or criminals (Battin et al., 1998; Esbensen \& Winfree, 1998; Miller, 2001; Taylor et al., 2007; Thornberry, 1998). That is, it has become a significant criminal justice problem in recent years. Although there are definitional differences of gang membership in gang studies (Matsueda et al., 2012) and implicit level of explanation and lack of agreement on unit of analysis in gang literature (Short, 1985), it is a universal problem. This study is divided into three contexts: American, European, and Turkish contexts. The first part explores the youth gang problem in the U.S. Because of diverse and rich studies in the U.S. about youth gangs, this section provides a broad discussion, particularly, of intervention and prevention strategies of this country. The next section is about youth gang problem in Europe. Most of the studies in this section are based on Eurogang definition and they are quite new and less comprehensive when compared with American example. The last section discusses youth gang problem in Turkey. Conceptual definition and perception of youth gangs in Turkey is quite different from those of the other countries discussed in this paper. Youth gangs are not perceived as a major threat in Turkey. Yet, the problem is addressed in the form of "troublesome street children" rather than as youth gangs in the Turkish context. With regards to intervention strategies, there does not exist any scientific process or outcome evaluations as in American context. Given the absence of evidence-based interventions in Turkey, this study may provide useful information on American and European experiences regarding youth gangs and the range of possible intervention strategies. This study will focus on definitional problem of youth gangs and whether policy responses have proved to be successful to prevent and solve youth gang problem. These responses are based on suppression, intervention, and prevention programs. While the study examined three different contexts in terms of youth gang problem, there are common recommendations that are applicable to the three contexts.

\section{American Context}

Youth gangs in the U.S. are considered as a prevalent problem. Howell (1998) stated that youth gangs emerged during the industrial era in the big cities due to rapid growths and shifts in particular in Chicago. During those times, gangs were considered in terms of nationality of the gang members such as being Italian or Irish. Then, ethnicity and race became major characteristics in order to categorize gangs in the U.S. African Americans and Hispanics were considered as dominant for members of the gangs. This threat was pervasive not only in big cities but also suburban counties, small cities, and rural counties (Howell, 1998). The threat was also recognized at the federal level by the Congress in 2006. For example, a Latino gang (MS-13) was founded by immigrants of El Salvador in California and became a threat in the East cost of America, in particular in Washington DC, Baltimore, and Northern Virginia 
(Franco, 2006). Gangs in the US typically tend to be visible, and well-organized groups that are large enough to control neighborhoods and engage in high levels of violence (Klein et al., 2006).

Definition of the youth gang is a problematic issue because studies define youth differently in the U.S. In a review of gang literature, in some studies, youth was considered as juveniles and between the ages of 15 and 24. Typical age range for gang members were between 12 and 24 . Another study in Seattle defined youth as between 12 and 18 in terms of age range. Some studies considered youth as being 13 or older (Howell, 1998; Howell \& Egley, 2005). This complexity for age range for youth gangs causes inconsistencies among studies in the U.S. Though those characteristics are mentioned in many studies, there is no clear conceptual definition of youth gangs in the U.S.

Howell (1998) states risk factors for youth gang members as coming from lower class, living in slums, which mean that it is more related with social disorganization of the community. Family, peer group, school, or individual characteristics are other issues which are considered as risk factors. Howell and Egley (2005) identified five risk factor levels based on the literature such as individual characteristics, family, school, peer groups, and community conditions. Those risk factors were associated with gang membership in the Seattle study. They also considered mediating and moderating effects for gang membership. For example, having weak social bonds can be moderating effect and having anti-social values may be mediating effect for gang membership.

Howell (1998) mentions that gangs tend to have different priorities and specialties. For example while African American gangs are involved in drug offenses, Hispanic gangs are involved in "turf-related" violence. He states that relationships among gang members also differ. For example, Hispanic gangs have more family like relationship among members and they have strong links to their neighborhoods. Howell (2007) stated, in another study, that gang membership was different for the race of the members. He examined a myth that all gang members are black males which was a mainly product of media. He stated that race or ethnicity was only dominant in gangs where they lived. For example, in African American community, black presence will be more dominant.

\subsection{Interventions in American Context}

There is a variety of intervention strategies in the US. Mobilization of the community is one of the most used methods to respond to youth gang problem. For example, the purpose of the Chicago Area Project (CAP) is to mobilize communities and neighborhoods by community based innovations to reduce juvenile delinquency through the implementation of organized recreation programs such as athletic contests, football, forming leagues for basketball, volleyball, and tennis. Club staff established ties with delinquent juveniles and became a role model for these youth. CAP's parole program was more readily evaluated than other mediating activities and it was found that the parole program produced successful results such as reduction in recidivism rate in the treatment group when compared to the control group. The second success of the program was that there was a substantial decline in official rates of delinquency. This program was also flexible that when neighborhood was dominated by Hispanics and Blacks, CAP had to adapt to this situation (Schlossman et al., 1984). Boys $\&$ Girls Club of America's (BGCA) efforts for preventing joining gangs was also significant. 
They implemented Gang Prevention through Targeted Outreach (GPTTO), designed to help youth stay out of gangs, and Gang Intervention through Targeted Outreach (GITTO), designed to help youth to quit their gang associated behaviors. The objectives of these two initiatives were to mobilize community resources to combat gang problem, implementing 50 prevention and 35 intervention programs. The results were promising because they dealt with this problem in multiple levels (Arbreton, 2002).

Schools are the main ground for intervention or prevention programs targeting youth gangs. Gottfredson and Gottfredson (2001) assessed school based gang prevention and intervention programs by describing student involvement in gangs, their characteristics and levels of involvement, how well those programs are being implemented in schools in terms of fidelity and to identify some features of successful intervention and prevention activities that schools can adopt to improve their programs. They stated that there were 781.800 gang prevention and 159.700 gang intervention activities but emphasized that these activities were not solely limited to gang prevention but also addressed behavioral problems. According to this report, there were differences and great variability for the implementation of gang prevention and intervention activities that threatened fidelity. Therefore, they recommended standardizing the employment of the activities which might also facilitate the evaluation of prevention and intervention activities.

GREAT program is the most well-known and prevalent school based gang prevention program in American context. Esbensen et al. (2002) evaluated the effectiveness of the GREAT program using cross sectional and longitudinal design in some of the U.S. cities. They found positive results such as helping middle school students avoid peer pressure to join gangs. Fritsch et al. (2003) reviewed several studies that evaluated gang prevention programs such as such as GREAT, CARE, and Arizona New turf programs and concluded that although these programs were well implemented, those programs did not have a major impact on gang problem and there was no empirical support for the effectiveness of those interventions.

Klein (1969) examined the effectiveness of the Group Guidance Project which involved detached worker procedures on four gang clusters in Los Angeles County over a four year period that started in 1961. It aimed to decrease mutual alienation between gang members, their families, and community adults and to decrease their involvement in delinquent acts. Detached workers used individual counseling, weekly club meetings, and special group activities such as dances, outgoings, and contacts with agency officials about school, recreation and employment concerns in order to achieve these goals. Detached workers did not spend most of their time with gang members, which might have prevented more positive effects of the intervention.

Suppression strategies are also popular for prevention and response to youth gangs. Sometimes moral panic is the main cause for suppression strategies because of the construction of the problem in the media. Bjerregard (2003) examined the benefits and abuses resulting from California Street Terrorism Enforcement and Prevention Act (STEP). According to this Act, a person will be guilty of a criminal offense if he/she actively participates in any criminal street gang with the knowledge that its members are involved in criminal activities or assists, furthers, or promotes any felonious criminal conduct by members of that gang. Although harsh policies might produce positive results in the short 
term, they are associated with unintended consequences. For example, the author examined the constitutionality of status and found that vagueness of the definition of gang and gang membership which might lead some abuses might give big power to law enforcement agencies to use their discretion. Identification of gang members by specific clothing, colors, and tattoos can be misleading, because some people may adopt the signatures of gangs in an effort protect themselves or simply out of aspiration.

Maxson et al. (2003) examined an intervention program (Civil Gang Injunction-CGI) which aimed to disrupt the routine activities of the gangs in the community. Injunctions were used to deal with gang problem in the neighborhood. Injunction system is described as when gang member creates public nuisance which is supported by evidence, then the Court requires these individuals not to commit the same thing. After the injunction is issued and targeted individuals are notified; then, those individuals can be arrested if they violate the conditions. These injunctions were criticized for the violation of people's constitutional rights such as free association as emphasized in the First Amendment. The authors contended that reduction in crime and revitalization of the community was the evidence of success.

Sometimes suppression strategies are supplemented by other interventions. Decker and Curry (2003) examined two anti-gang programs in St. Louis which are related with suppression and prevention called as Anti-Gang Initiative (AGI). Suppression strategy was implemented by law enforcement agencies and gang members were incarcerated by using some strategies such as arrest, imprisonment, and surveillance. Social intervention was the second intervention, which focused on emergency interventions such as employing crisis intervention, treatment of youths and their families. Organizational change was the third strategy in which organizations created task forces and focused on proximate causes of gangs. Community mobilization was the fourth strategy in which community agencies were mobilized to address the fundamental causes of gangs. Social opportunities were the fifth strategy in which job opportunities were expanded and education placements were provided. Although Decker and Curry (2003) did not find any statistically significant results, they contended that a multi-faceted approach to gang problem through the implementation of alternative interventions simultaneously was a promising approach. Therefore, this initiative was implemented in Detroit later. Bynum and Varano (2003) measured the impact of Anti-Gang Initiative intervention program which was based on suppression approach in Detroit. The result showed that the intervention was effective.

\section{European Context}

Youth gang research in Europe is not an old phenomenon as in the U.S and although many European countries face gang problem in their countries, they are hesitant to refer to them as "gang" when they compare these groups with gangs in America. Because of having many legal/illegal immigrants, most of the European countries face youth gang problem. Each country may have different gang problem because of having different ethnicities in their countries. Therefore, a standard definition of youth gang was needed in the European gang research and Eurogang definition was developed. A street gang is defined as "any durable, street-oriented youth group whose involvement in illegal activity is part of its group identity" (Weerman et al., 2009).

While there are many different race and ethnicities in Europe which are related to youth gang 
problem, they have a common ground marginalization and isolation from the society they live in. For example, Lien (2005) examined Pakistani gangs in Oslo; Gemert (2005) studied Moroccan youth gang in Netherlands; and Weitekamp and Kerner (2005) examined Aussiedlers who are Russians of German descent. These groups remained in their ethnic group and engaged in violence since they found themselves as losers due to economic condition. They were not integrated in the society and recruited new members in their segregated neighborhoods. In those studies, the authors found that all those groups had problems and had adaptation problems in their society. Overall, while American gangs were mostly composed of Hispanics and blacks, gangs in Europe were mostly composed of ethnic or national minorities reflecting immigration patterns of the country such as Turks, Pakistanis, Algerians, Albanians and other ethnicities (Klein et al., 2006).

Immigrants in European countries find themselves between their traditions, traditional life styles and lifestyle of the country they migrated. They find it difficult to adapt to the new life style and culture. For example Gemert (2005) state that Moroccan immigrants in the Netherlands spoke Dutch poorly, had lower levels of income and education. They were not successful in the schools and dropped out of school easily. Sperone youth gang members did not have any diploma from schools (Gatti \& Angelini, 2005). Aussiedlers also had similar problems. Their skills and education level were not enough to compete with their German counterparts which eventually led to their marginalization due to their failure to integration into society and job market (Weitekamp et al., 2005).

Because of this marginalization and not feeling as a part of the society, they do not hesitate to use violence in their community and neighborhoods. For example, Sperone group in Southern Italy uses violence against people in their neighborhood (Gatti \& Angelini, 2005). Moroccan youth group in the Netherlands have problems with citizens of the neighborhood and they use intimidation and threats to suppress citizens who oppose or complain about them. They use their presence in the neighborhood as an advantage and give the message that police cannot be present all the time where they live (Gemert, 2005).

Youth gangs in Europe engage in a variety of crimes. For example, Moroccan youth gangs in the Netherlands are known to commit offenses such as assault, theft, vandalism, threats, attempted murder, fights, nuisance, arson, and stickups (Gemert, 2005; Gatti \& Angelini, 2005).

Group dynamics of youth gangs in Europe is different from their U.S. counterparts because of being immigrants in the society. Groups mostly consist of males particularly in Muslim youth gangs, because according to their traditions, females should remain at home in order not to dishonor their family by protecting their virginity (Gemert, 2005). Sperone youth gang in Italy has female members and they are mostly girlfriends of male gang members. They are ready to take action to defend their positions (Gatti \& Angelini, 2005).

Age of the youth gang members differ. For example, age range for Moroccan youth gang is between 16 and 20 with an average of 18 (Gemert, 2005). Sometimes it is difficult to define them as youth gang because gang members are mostly adults. For example, Lien (2005) examined Pakistani youth gangs in Oslo and found that age of the members of 'Young Gang' reached to forty and A-Gang members' age was between 20 and 30. 
Youth gangs establish their structure on kinship or ethnicity. For example, the main bond among Moroccan members is their ethnicity. Therefore, young Moroccans identify themselves with their ethnic identity rather than their Dutch identity and they do not feel themselves belonging to the place where they live in (Gemert, 2005). Pakistani youth gangs in Oslo also have strong kinship relations. For example, in B-Gang, there were seven brothers (Lien, 2005). They also have close bonds to their members even who are imprisoned. They write and visit them in the prison as in Sperone youth gang in Italy (Gatti \& Angelini, 2005).

Youth gangs in Europe, unlike their U.S. counterparts, mostly do not have any symbols or any signs which represent them. For example, Moroccan youth group does not use any sign, clothes, symbols, or tattoos. They even do not have any name for their group and according to their members they do not perceive their groups as gangs but just a bunch of friends who have known each other for a long time. Therefore, it is difficult to identify them as group members (Gatti \& Angelini, 2005; Gemert, 2005)

Gang members who are from immigrant families have become more autonomous as gatekeepers for their elderly family members in the daily life, because their families cannot speak the language of the country, have low education which have prevented their integration into the society (Gemert, 2005). Parents of the Pakistani youth gangs in Oslo do not have more authority on their children due to living in a foreign country where their authority is curtailed by the laws or their lack of integration into the society (Lien, 2005).

\subsection{Interventions at European Context}

Youth gang problem in Europe is typically perceived in terms of ethnicities; therefore, interventions targeted ethnic minorities. For example, the problem of Moroccan youth became prevalent in 1998 when they had conflict with the police. A riot, which happened in 1998 in a neighborhood where Moroccans lived, was considered as turning point and received more public and police attention leading to several intervention or prevention programs (Gemert, 2005).

There were interventions in southern Italy for Sperone gang to integrate them into the society and provide some alternatives or help them continue their schools; however due to attrition or having difficulties to organize some events, those interventions failed. Moreover, economic and social problems in the neighborhood prevented the implementation and effectiveness of interventions (Gatti \& Angelini, 2005).

There are multiple effects of influence on gang problem such as poverty, isolation from the society, unemployment which should be dealt with local and national policies; family problems, child neglect, or individual problems. Therefore, there is a debate on what strategies should be implemented in order to prevent this problem. By using Eurogang definition, Carlson and Decker (2005) conducted a study in Norway, Denmark, and with some additional information about Sweden and compared to the U.S. experience. The interventions implemented by local municipalities and NGOs included services such as youth clubs and youth houses to prevent crime, which received support from the government. The study found that youth clubs were ineffective because youth behaving improperly were expelled.

Suppression strategies were also implemented. In Norway, supervision of informal leaders 
and core members, imprisonment and quick investigation resulted in positive results unlike in Denmark. Suppression strategies also led to a political debate in Scandinavian countries on the imprisonment of gang members under 18 and its cost to country. Right wing political parties typically favored harsh policies and stronger punishments while left wing political parties were in favor of treatment or other non-punitive measures. Harsh policies against gangs in Denmark backfired resulting in increased levels of violence in the community as well as strengthening the bonds among gang members. This led the police to prefer cooperative methods with local city administration to deal with this problem. The other strategy was to mobilize ethnic parents as night owls to monitor the activities of their kids at night, which the authors declared as effective, although we are not aware how they measured this success (Carlson \& Decker, 2005).

Carlson and Decker (2005) introduced other methods that are the combination of social control and social opportunity measures. For example, the worrying conversation is conducted by police organization in Norway where the parent and the delinquent juvenile come to the police station and police inform the parent about the situation and also talk with the juvenile about the possible consequences of his actions.

Exit Parent Groups targets delinquent youth groups and gangs where parents are paired up with their children and parents are provided with an opportunity to restore parental control. Complementary Methods is similar to Exit Parent Group but this method is also fostered with a welfare system through the provision of leisure activities, education, and jobs. What these strategies have in common is the building of trust and personal relationship. Former criminal youth at times were used in order to build this relationship (Carlson \& Decker, 2005).

\section{The Turkish Context}

Although there is not a perceived youth gang problem, troublesome street children problem can be considered as a common youth problem in Turkey. Street children live on the streets on a permanent basis and are detached from their families. They are highly involved in criminal behavior including substance use. They are also disproportionately victimized. They tend to come from families with lower levels of education and income and are likely to have been physically abused by their families. These children are also out of the education system. In 1950s, they were identified as "under bridge children" because they tended to choose places under the bridge to sleep and live. Genar (2007) defines street children as juveniles under 18 living on the street permanently with peers who they hang out with, with less or no bonds to their families, and earning money on the streets. However, there is no standard definition of street children and sometimes adults are considered street children.

Street children, with their increasing numbers, are a growing problem particularly in big cities in both west and east regions of Turkey such as Istanbul, Ankara, Diyarbakir. Turkish Statistics Institute estimated that 625,000 children were at risk of being street children in Istanbul in 2004 (Gunes \& Kalayci, 2004).

The reasons of being in a street children group are the need for protection/shelter and survival on the streets. Street children tend to have weak or no bond with their family and school. Instead, they have strong bonds with their peer group on the street and are involved in many criminal activities such as robbery, theft, and assault in order to get money (Dikici, 2008; 
Güneş \& Kalayc1, 2004; UNICEF, 2009). Öğel et al. (2004) stated that street children were sexually and physically abused; tended to come from overcrowded domestic immigrant families to big cities; had low socioeconomic status; exposed to peer influence; had a separated family or an unemployed father; and had low education level. Therefore, they choose to run away from their home to big cities such as Istanbul. Genar (2007) found that almost $34 \%$ of the street children who lived on streets of Istanbul had run-aways. In overcrowded families, it is difficult for parents to control their children in big cities due to the challenges of the social life of a big city and poor economic conditions of the family (Alp, 2010; Değirmencioğlu et al., 2008). Volatile substance, inhalants, and solvent abuse were considered as risk factors for street children that harm their overall health. They mostly commit crime when they are under the influence of volatile substances. Violence may be considered as a part of masculinity among some street children. They do not hesitate to use violence when they have to in order to prove their masculinity. Violence is typically learned in the family environment where they have been exposed to high levels of domestic violence by their father (Genar, 2007).

Street children groups evolve around some rules, which are called "street rules". For example, each group member has to share what he/she earns. They do not call themselves with their real names but use nicknames. When they were wounded, they treat themselves on their own. When they do not want anyone to understand what they talk about, they use a special language which is called 'bird language'. Informants are driven out of the group and they can no longer become part of any other groups and have to live on their own alone on the streets, which is very dangerous for them. (Alp, 2010; Genar, 2007)

\subsection{Interventions in Turkish Context}

It is important to identify the root causes that lead children to live on the streets. There are multiple levels of influence; therefore, interventions should involve different contexts in which governmental agencies, NGOs, communities, families, and schools should be mobilized in order to prevent and protect those children. Due to not having families, or having abusing families, they need to be provided safe environments in which they can be reintegrated into the society (UNICEF, 2009). However, there are not broad and well-designed intervention or prevention programs for troublesome street children in Turkey but only local interventions mostly carried out by some NGOs and police organizations.

Şanliurfa Police Department implemented Tourism Volunteer Project to train troublesome street children in collaboration with some NGOs and the local community. After 6 months of training, these youth were given special uniforms and authorization to guide tourists. Through this project, 55 street children were rescued from the streets. Those children were also given an opportunity to continue their education. They were also encouraged to attend other vocational trainings (Dikici, 2008).

Şanliurfa Police Department also addressed volatile substance, inhalant, and solvent sniffing problem among street children in cooperation with psychologists and social workers through approaches such as individual-group counseling, family counseling, and temporary removal of those children from risky environments. The children were also provided with food, and clothing by the police and medical care at health centers. The police approached the children as friends rather than law enforcement officers. The result of this intervention was successful. 
Between 2003 and 2007, out of 82 contacted sniffers, 71 of them quitted sniffing (Dikici, 2008).

Another activity for street children who were also sniffers was celebrating their final school reports before summer vacation by gathering at the police guest house. In spring, the police also organized activities such as kite festival contest and swimming courses. The children also participated in tree-planting activities and every single child had his/her own tree tagged with his/her name on it. These activities were also carried out in participation of the street children together with school children in an effort to have the street children form healthy bonds with mainstream kids. Street children were also taken to theaters with police. The movies that conveyed positive messages were particularly selected. The police also organized basketball and soccer tournaments with the participation of street children. These activities were found to produce positive results. The kids who participated in the activites reported having had amazing moments during those activities and promised not to engage in any illegal activity.

Zeytinburnu County Council (a county of Istanbul) (2006) implemented some intervention which involved government organizations, NGOs, and the community. The Council founded juvenile and youth centers to help support the development of juveniles in social, educational, and cultural aspects. The Council also established street children coordination centers that are composed of street offices, shelters, and mobile patrols. Shelters are particularly important to protect street children. Alp (2010) stated that street children commit crimes in winter to spend the cold days in prison that provides a warm environment and food.

\section{Conclusion}

In the three different contexts studied here, it is clear that there is no clear definition of youth gang. Therefore, in order to deal with this problem efficiently, there should be a clear conceptual definition of youth gang in terms of age range, activities of the gangs, crime types, etc., which should provide consistency in the literature of the youth gang.

Multiple levels of influence should be considered for youth gang members such as individual characteristics, peers, family, and community. However, there is a dearth of research that investigate what factors influence youth gang membership. Qualitative studies that investigate why juveniles join youth gangs can inform intervention design.

Risk factors for each context and structure of the youth gangs may be different. For example, Weerman and Esbensen (2005) compared youth gangs in the U.S. and Netherlands. They found that while risk seeking and impulsivity were associated with gang membership in Netherlands, only risk seeking was associated with gang membership in the US. Peer pressure did not have any significant effect in the Dutch sample while it was the second strongest predictor in the US sample. Gang members in both samples had differences in terms of gender composition in the gang that there were more female and male members in the gangs in the US and the size of the gangs were bigger than Dutch gangs. The U.S. gangs had also more symbols, names, rules, constant meetings, and leaders than their Dutch counterparts. In this regard, before planning intervention or prevention programs, risk factors should be carefully identified.

The studies that evaluated interventions in Europe were descriptive. So we do not know 
whether they were successful or not and how they measured the effectiveness of the interventions (Carlson \& Decker, 2005). Some of the interventions in the U.S. were evaluated. As in Europe, none of the interventions in Turkey were evaluated. The intervention and prevention programs should be evidence-based and evaluated to understand whether the initiatives have achieved their objectives. Program evaluations can also provide useful information about what works, which is particularly of importance to those who design interventions elsewhere. Gravel et al. (2013) provided a comprehensive review of gang response programs and offered a typology of programs that is very useful. The reason for this research was that there were inadequate frameworks to compare similar gang control strategies, which limited the ability to determine the effectiveness of existing programs. Some programs did not specify clear objectives; some did not link between the activities of the program and their specified objectives; some programs only focused on general objective ignoring specific needs; and some did not include evaluation component in the design of the program. Therefore they proposed a logic model that allowed the use of current knowledge of gang problem in a efficient manner.

Most of the interventions were individual or family based; therefore, did not take into account macro level structural factors such as unemployment, poverty, or marginalization of youth in the society. Especially, at times of economic crises, this problem would be more prevalent with the increasing rate of illegal or legal immigration to the European countries (Carlson \& Decker, 2005). Moreover, in gang studies individual level correlates such as social learning or strain, group processes in gangs such as fear of ridicule or fearlessness, and macro correlates of gangs and gang behaviors such as taking neighborhoods, communities, and cities as units of analysis (Decker et al., 2012) should be examined carefully in order to produce accurate intervention or prevention strategies.

When developing a program, it is important to bring all necessary stakeholders to the table (Winfree et al, 1999). There should be cooperation among different governmental agencies, municipalities, NGOs and any organization that are needed to prevent youth gang problem in the community. Boston's youth violence prevention program and The Little Village Project are good examples for cooperation among different organizations (McDevitt et al., 2003; Spergel \& Grossman, 1997).

Most of the mentioned intervention or prevention programs were only implicitly related to theories or were not informed by any theory at all. Theories provide a guiding framework for program evaluation. Theory based intervention and prevention programs will be stronger in design and more externally valid, that is, generalizable than other evaluations and will have a greater influence on policy makers.

Most of the intervention or prevention programs did not have a control group for youth gangs or geographic area so that comparison could not be made to understand whether the treatment really did work or not. Therefore, in those circumstances, time series design could be used in order to see the influence of the treatments. When there is no comparison group and evaluations are funded after the projects began, pretest-posttest design may be implemented as Williams et al. (2002) did. Moreover, pretest-posttest design with nonequivalent dependent variable and a comparison group matched on some criteria may be used for evaluations. For stronger conclusions, there might be also prospective longitudinal studies that follow 
participants some time upon the completion of the program so that we can be surer about the effects of the programs.

Most of the suppression strategies are based on new legislation and policies which may be violated by law enforcement agencies if legislation is not well defined. Therefore, as Bjerregard (2003) suggested definition of gangs, members, and gang related activities should be well defined. Second, definition should target hard-core and committed members. Third, gang related offenses should involve only serious offenses.

Evaluation of legal impact is important to examine the effectiveness of legislative changes. Legal impact research does not need a special kind of methodology and can be implemented with standard methodology procedures such as time series analysis, survey research etc. to examine the impact of the legal changes. True experimental design cannot be feasible in legal impact research because statutes and court decisions can never be applied to randomly assigned groups, exempting control groups from their mandates. Therefore, quasi-experimental design, multiple time series designs in particular, is more appropriate for legal impact research (Horney \& Spohn, 1990).

Turkish National Police and Gendarmerie are the two principle organizations with mandated responsibility for security in the Turkish context. They deal with juvenile delinquents as well as street children who have never committed crime. It is highly recommended that the police and the gendarmerie organize workshops with the participation of psychologists, social workers, and so forth in an effort to mobilize resources to deal with troublesome street children problem (UNICEF, 2009). It is also highly recommended that vocational training be provided to street children (UNICEF, 2009) to improve their job skills and employability, which should eventually contribute to their reintegration into the society through social bonds.

\section{References}

Alp, H. (2010). Sokak cocuklari sahiden bizim mi? Taraf. Retrieved on March 22, 2010, from http://www.taraf.com.tr/haber/46396.htm

Arbreton, A. J. A., \& McClanahan, W. S. (2002). Targeted Outreach: Boys and Girls Clubs of America's Approach to Gang Prevention and Intervention. Philadelphia, PA: Public/Private Ventures.

Battin, S. R., Hill, K. G., Abbott, R. D., Catalano, R. F., \& Hawkins, J. D. (1998). The contribution of gang membership to delinquency beyond delinquent friends. Criminology, 36, 93-115. http://dx.doi.org/10.1111/j.1745-9125.1998.tb01241.x

Bjerregaard, B. (2003). Antigang legislation and its potential impact: The promises and pitfalls. Criminal Justice Policy Review, 14(2), 171-192. http://dx.doi.org/10.1177/0887403403014002002

Bynum, T. S., \& Varano, S. P. (2003). The anti-gang initiative in Detroit: An aggressive enforcement approach to gangs. In S. H. Decker (Ed.), Policing gangs and youth violence. Thomson Wadsworth, Belmont, (pp. 214-238).

Carlson, Y., \& Decker, S. H. (2005). Gang and youth violence prevention and intervention: Contrasting the experience of the Scandinavian welfare state with the United States. In S. H. Decker \& F. M. Weerman (Eds.), European street gangs and troublesome youth groups. (pp. 259-286). AltaMira Press Oxford, UK. 
Decker, S. H., Melde, C., \& Pyrooz, D. C. (2012). What do we know about gangs and gang members and where do we go from here? Justice Quarterly, 30(3), 369-402. http://dx.doi.org/10.1080/07418825.2012.732101

Decker, S. H., Curry, G. D. (2003). Suppression without prevention, prevention without suppression: Gang intervention in St. Louis, In S. H. Decker (Ed.), Policing gangs and youth violence. (pp. 191-213). Thomson Wadsworth, Belmont.

Degirmencioglu, S. M., Acar, H., \& Baykara-Acar, Y. (2008). Extreme forms of child labor in Turkey. Children \& Society, 22, 191-200. http://dx.doi.org/10.1111/j.1099-0860.2008.00150.x

Dikici, A. (2008). Preventing the PKK's misuse of children by introducing community policing: The Sanliurfa case. Defense Against Terrorism Review, 1(2), 119-138.

Esbensen, F. A., Freng, A., Taylor, T. J., Peterson, D., \& Osgood, D. W. (2002). National evaluation of the G.R.E.A.T. Program. In W. L. Reed \& S. H. Decker (Eds.), Responding to Gangs: Evaluation and Research. (pp. 139-167). National Institute of Justice, U.S. Department of Justice, Washington DC.

Esbensen, F. A., \& Winfree, L. T. (1998). Race and gender differences between gang and non-gang youth: Results from a multi-site survey. Justice Quarterly, 15, 505-526. http://dx.doi.org/10.1080/07418829800093861

Franco, C. (2006). Youth gangs: Legislative issues in the 109 ${ }^{\text {th }}$ congress (2006), (pp. 1-24).

Fritsch, E. J., Caeti, T. J., \& Taylor, R. W. (2003). Gang suppression through saturation patrol and aggressive curfew and truancy enforcement: A quasi-experimental test of the Dallas anti-gang initiative. In S. H. Decker (Ed.), Policing gangs and youth violence. (pp. 102-130). Thomson Wadsworth, Belmont.

Gemert, F. V. (2005). In the grip of the group. In S. H. Decker \& F. M. Weerman (Eds.), European street gangs and troublesome youth groups. (pp. 11-29). AltaMira Press, Okford, UK.

Genar. (2007). Istanbul'da siddet ve siddetin sosyolojik arka plani arastirma raporu. Retrieved on March 23, 2010 from http://www.genar.com.tr/files/istanbul_siddet_rapor.pdf

Gottfredson, G. D., Gottfredson, D. C. (2001). Gang problems and gang programs in a national sample of schools: Summary. Gottfredson Associates, Inc., Ellicott City, MD. Gunes, S., Kalayci, A.R., 2004. Sokakta yasayan/calisan cocuklar: Tespitler ve cozum onerileri. Retrieved on March 22, 2010 from http://aile.gov.tr/index/index/konu/169

Horney, J., \& Spohn, C. (1990). Issues in legal impact research. In J. G. Weis (Ed.), Measurement issues in criminology. (pp. 1-20). Springer-Verlag, New York. http://dx.doi.org/10.1007/978-1-4613-9009-1_8

Howell, J. C. (2007). Menacing or mimicking? Realities of youth gangs. Juvenile and Family Court Journal, 58(2), 39-50. http://dx.doi.org/10.1111/j.1755-6988.2007.tb00137.x

Howell, J. C. (1998). Youth gangs: An overview. Juvenile Justice Bulletin. Retrieved on March 12, 2010 from http://www.ncjrs.org/pdffiles/167249.pdf

Howell, J. C., \& Egley, A. (2005). Moving risk factors into developmental theories of gang membership. Youth Violence and Juvenile Justice, 3, 334-354. http://dx.doi.org/10.1177/1541204005278679 
Klein, M. W. (1969). Gang cohesiveness, delinquency, and a street-work program. Journal of Research in Crime and Delinquency, 6(2), 135-66. http://dx.doi.org/10.1177/002242786900600204

Klein, M. W., Weerman, F. M., \& Thornberry, T. P. (2006). Street gang violence in Europe. European Journal of Criminology, 3(4), 413-437. http://dx.doi.org/10.1177/1477370806067911

Matsueda, K. N., Esbensen, F. A., \& Carson, D. C. (2012). Putting the "gang" in "eurogang": Characteristics of delinquent youth groups by different definitional approaches. In F. A. Esbensen \& C. L. Maxson (Eds), Youth gang in international perspective: Results from the Eurogang program. (pp. 17-33). Springer, New York.

Maxson, C. L., Hennigan, K., \& Sloane, D. C. (2003). For the sake of neighborhood: Civil gang injunctions as a gang intervention tool in southern California. In S. H. Decker (Ed.), Policing gangs and youth violence. (pp. 239-266). Thomson Wadsworth, Belmont, CA.

McDevitt, J., Braga, A. A., Nurge, D., \& Buerger, M. (2003). Boston's youth violence prevention program: A comprehensive community-wide approach. In S. H. Decker (Ed.), Policing gangs and youth violence (pp. 53-76). Thomson Wadsworth, Belmont, CA.

Miller, J. (2001). One of the Guys: Girls, Gangs, and Gender. Oxford University Press, New York.

Ogel, K., Yucel, H., \& Aksoy, A. (2004). Istanbul'da sokakta yasayan cocuklarin ozellikleri. Yeniden Bilimsel Arastirma Raporlari, Istanbul.

Ozsuer, S. (2007). Ulusal basin acisindan sokak cocuklari problem. Retrieved on March 21, 2010 from http://www.sosyalhizmetuzmani.org/uba.htm

Pope, C. E., \& Lovell, R. (1997). Gang prevention and intervention strategies of the Boys and Girls Clubs of America. Free Inquiry-Special Issue 2: Gangs, Drugs \& Violence, 25(1), 117-126.

Schlossman, S., Zellman, G., \& Shavelson, R. (1984). Delinquency prevention in south Chicago: A fifty-year assessment of the Chicago area project. Santa Monica, CA: Rand.

Short, J. F. (1985). The level of explanation problem. In R. Mrier (Ed.), Theoretical methods in criminology (pp. 51-74), Beverly Hills, CA: Sage.

Spergel, I. A., \& Grossman, S. F. (1997). The little village project: A community approach to the gang problem. Social Work, 42, 456-470. http://dx.doi.org/10.1093/sw/42.5.456

Taylor, T. J., Peterson, D., Esbensen, F. A., \& Freng, A. (2007). Gang membership as a risk factor for adolescent violent victimization. Journal of Research in Crime and Delinquency, 44, 351-380. http://dx.doi.org/10.1177/0022427807305845

Thornberry, T. P. (1998). Membership in youth gangs and involvement in serious and violent offending. In R. Loeber \& D. P. Farrington (Eds), Serious and violent juvenile offenders: Risk factors and successful interventions (pp. 147-66). Sage, Thousand Oaks.

UNICEF. (2009). Making a difference for children: Street children. Retrieved on March 21, 2010 from http://www.unicef.org/turkey/dn/cp8.html.

Weerman, F. M., \& Esbensen, F. A. (2005). A cross-national comparison of youth gangs: The United States and Netherland. In S. H. Decker \& F. M. Weerman, (Eds.), European street 


\section{Macrothink}

gangs and troublesome youth groups (pp. 219-255). AltaMira Press, Oxford, UK.

Weitekamp, E .G. M., Reich, K., \& Kerner, H. J. (2005). Why do young male Russians of German descent tend to join or form violent gangs? In S. H. Decker \& F. M. Weerman (Eds.), European street gangs and troublesome youth groups. (pp. 81-104). AltaMira Press, Oxford, UK.

Williams, K., Curry, G. D., \& Cohen, M. I. (2002). Gang prevention programs for female adolescents: An evaluation. In W. L. Reed \& S. H. Decker (Eds.), Responding to Gangs: Evaluation and Research (pp. 225-263). National Institute of Justice, U.S. Department of Justice, Washington, DC.

Winfree, L. T., Lynskey, D. P., \& Maupin, J. R. (1999). Developing local police and federal law enforcement partnerships: G.R.E.A.T. as a case study of policy implementation. Criminal Justice Review, 24(2), 145-168. http://dx.doi.org/10.1177/073401689902400203

Zeytinburnu, K. K. (2006). Fiziksel konular calisma grubu raporu. Retrieved on March 21, 2010

from http://zeytinburnu.bel.tr/varliklar/Turkce/dosya/mevzuatlar/yerel_gundem/Sosyal_konular.pdf

\section{Copyright Disclaimer}

Copyright reserved by the author(s).

This article is an open-access article distributed under the terms and conditions of the Creative Commons Attribution license (http://creativecommons.org/licenses/by/3.0/). 